\title{
FMC7 Negative
}

National Cancer Institute

\section{Source}

National Cancer Institute. FMC7 Negative. NCI Thesaurus. Code C162074.

An indication that expression of the B-lymphocyte antigen FMC7 has not been detected in a sample. 